\title{
MEMAHAMI KARAKTER ATLET PELAJAR MELALUI OLAHRAGA PANAHAN
}

\author{
Betrix Teofa Perkasa Wibafiet Billy Yachsie ${ }^{1}$, Siis Suhasto ${ }^{2}$ \\ ${ }^{1}$ Ilmu Keolahragaan, Universitas Negeri Yogyakarta, \\ Yogyakarta, Indonesia \\ e-mail: betrixbilly@uny.ac.id, siissuhasto972@gmail.com
}

\begin{abstract}
Abstrak
Olahraga panahan mempunyai peran stategis untuk membentuk karakter atlet pelajar di Kabupaten Banyumas. Penelitian ini adalah penelitian ex post facto untuk menemukan penyebab perubahan perilaku, gejala atau fenomena yang disebabkan oleh peristiwa pribadi, metode yang digunakan dalam penelitian ini adalah survei. Populasi dalam peneltian ini ada 88 atlet pelajar yang di ambil dengan purpose sampling didapat sempel 30 atlet. Instrumen yang digunakan adalah angket yang telah diujicobakan dengan taraf signifikansi $5 \%$ diketahui validitas 0,312 dan reabilitas 0,911 . Teknik analisis data yang digunakan dalam penelitian ini adalah deskriptif dengan presentase. Berdasarkan hasil penelitian karakter atlet pelajar panahan di Kabupaten Banyumas sebagian besar pada kategori baik dengan persentase sebesar 37,5\%, pada ketegori cukup sebesar $25 \%$, pada kategori kurang sebesar $17,5 \%$ dan pada kategori sangat kurang sebesar $10 \%$, dan kategori sangat Baik $10 \%$. Hasil penelitian tersebut disimpulkan diketahui karakter atlet pelajar panahan di Kabupaten Banyumas adalah baik.
\end{abstract}

Kata kunci: personalitas; atlet pelajar; olahraga panahan.

\begin{abstract}
Archery has strategic role shape the character student athletes Banyumas Regency. This research ex post facto study find the causes of changes behavior, symptoms or phenomena caused by personal events, the method used in this research is survey. The sample this study were 30 athletes who were taken by purposive sampling. The instrument used is questionnaire that has been tested with a significance level of 5\% with a known validity of 0.312 and reliability of 0.911 . The data analysis technique used this research is descriptive with percentage. Based on the research results, the character of archery student athletes Banyumas Regency mostly the good category with a percentage of $37.5 \%$, the sufficient category by $25 \%$, the less category by $17.5 \%$ and the very poor category by $10 \%$, and the very poor category. Good $10 \%$. The results of the study concluded the character of archery student athletes Banyumas Regency was good.
\end{abstract}

Keywords : personality; student athletes; archery.

\section{PENDAHULUAN}

Pendidikan karakter merupakan penghayatan dalam bentuk sikap, dan pengalaman yang sudah pernah dilakukan dengan mengamalkan nilai-nilai luhur yang benar dan terbukti nyata (Chanifah \& Samsudin, 2020). Berkaitan dengan persoalan-persoalan mengenai kenakalan remaja dan sebagainya pendidikan karakter dapat dibantu dengan memberikan solusi melalui kegiatan-kegiatan yang ada diluar sekolah maupun dalam lembaga pendidikan formal untuk mewadahi pelajar mengembangkan peran karakter pelajar melalui kegiatan yang positif seperti menekuni sebuah olahraga (Rukmini, 2021). Menurut Sumaryanto (2015) menjelaskan bahwa peran olahraga sangatlah penting saat mengembangkan karakter anak, hal ini dijelaskan bahwa olahraga terdapat beberapa nilai-nilai olahraga seperti sportifitas, kedisiplinan, kejujuran, keindahan dan nilai patriotisme. Dapat disimpulkan penanaman dan pelaksanaan pendidikan karakter tidak hanya sekedar mentransfer ilmu pengetahuan dan melatih suatu keterampilan tertentu melainkan harus ada sebuah proses. Menurut Hermino and Arifin (2020) siswa teladan, serta pembiasaan dan pembudayaan dalam lingkungan peserta didik dalam lingkungan sekolah, keluarga, masyarakat, maupun media masa. Dilingkungan sekolah 
merupakan tempat untuk melaksanakan dan menanamkan suatu pendidikan karakter salah satunya melalui olahraga panahan.

Panahan yaitu olahraga yang sudah ada pada zaman dahulu kala. (Sezer, 2017; Prasetyo, 2013; Nawir, 2011; Putri, 2019) Cabang olahraga ini adalah kombinasi dari seni dan olahraga. Seni di artikan membutuhkan jiwa sabar dan tekun, Sedangkan olahraga di artikan menggunakan otot dan menyebabkan tubuh berkeringat (Yachsie, 2019). Berdasarkan penelitian Verawati and Valianto (2020) panahan juga mempunyai manfaat dari segi psikologis atau mental olahraga dapat meningkatkan kepercayaan diri, kerjasama tim, kemampuan bersosialisasi, kesabaran, kepedulian, empati, kasih sayang, pengendalian emosi, inisiatif, kemampuan perencanaan, dan problem solving. Melihat kegiatan panahan tersebut dapat disimpulkan bahwa kegiatan panahan bisa dijadikan alat untuk mengembangakan pembentukan mental.

Pembinaan karakter di Kabupaten Banyumas terutama pada usia dini, masih mengalami beberapa permasalahan diantaranya yaitu di lingkungan keluarga, minimnya pengetahuan orang tua mengenai pembinaan karakter sejak usia dini memberikan dampak di dalam perkembangan karakter anak, serta ditambah lagi kurangnya pembinaan oleh pemerintah seperti seminar, workshop pengetahuan karakter sejak usia dini yang dilakukan kegiatankegiatan disatuan pendidikan dan diluar jam pembelajaran masih sangat jarang dan minim dilakukan di Kabupaten Banyumas.

Sesungguhnya keadaan tersebut akan berpengaruh terhadap karakter dasar anak. Tentunya anak harus baik dalam spiritual, disiplin, bertanggung jawab, berpandangan luas, optimis, pandangan spiritual yang mendalam, dan nasionalisme yang kuat (Mackenzie, 2017). Karakter anak harus dibentuk mulai usia dini dan diawali dari lingkungan keluarga (Alif et al., 2020). Selaras dengan penelitian Sameroff and Seifer (2021) pemberian pendidikan karakter anak yang baik sejak dini harus diinternalisasikan ke dalam setiap perilaku individu anak yang diawali di lingkungan keluarga dilanjutkan dalam pendidikan di sekolah-sekolah atau lembagalembaga masyarakat serta kegiatan anak-anak diluar sekolah.

Berdasarkan hasil observasi masyarakat di Kabupaten Banyumas masih belum mengetahui secara pasti bahwa persoalan-persoalan mengenai kenakalan remaja dan sebagainya dapat dibantu dengan memberikan solusi melalui kegiatan-kegiatan yang ada diluar sekolah maupun dalam lembaga pendidikan formal untuk mewadahi pelajar mengembangkan peran karakter pelajar melalui kegiatan yang positif seperti menekuni sebuah olahraga. Olahraga memiliki peran strategis dalam internalisasi karakter yang baik. Hal ini dapat dilakukan dengan memberikan nasihat, simulasi dan diskusi, misalnya dalam praktik nyata permainan dan latihan anak.

Kondisi yang terjadi saat ini di Kabupaten Banyumas yaitu menjelang sore hari masih banyak anak-anak remaja yang melakukan kegiatan yang kurang positif seperti melakukan konvoi kendaraan, kegiatan nongkrong di area jembatan dan masih banyak lagi yang belum tersalurkan dengan baik dan masih banyak anak- anak remaja yang melakukan kegiatan.

Melihat kegiatan yang kurang baik ini tentunya dapat dimanfaatkan sebagai salah satu penghambat pengembangan karakter anak untuk mencari jati dirinya (Hasanah \& Deiniatur, 2020). Didukung dengan penelitian penelitian dari Kurniawati (2018); Wardana, Adi, and Suwiwa (2017) bahwa atlet yang berprestasi bisa di lihat dari pribadi yang tidak menyimmpang di samping pribadi yang baik dari segi sikap dan lingkungan sangat menentukan prestasinya. Dengan di dukung penelitian (Vanagosi \& Dewi, 2019) adanya evaluasi yang dilakukan dapat mengetahui kelemahan dan kekurangan program pembinaan yang selama ini telah diterapkan. Selaras dengan penelitian (Suratmin, Artanayasa, and Budiawan 2018; Sugandini 2018) pencapaian prestasi olahraga tertinggi merupakan akibat langsung dari lingkungan dan evaluasi pada cabang olahraga yang menuntut prestasi akademik dan pertandingan.

Dapat disimpulkan Panahan memiliki peranan dalam pelaksanaan pembentukan karakter yaitu olah hati, olah fikir, olah raga, dan olah karsa meliputi: a) konsisten, yaitu saat menembakkan anak panahan ke arah target yang ditentukan; b) optimis, yaitu ketika pemanah bisa mengendalikan dirinya dan membidik dengan tepat agar anak panah menuju kearah 
sasaran yang tepat; c) fokus, yaitu saat latihan membidik, melepaskan anak panah ke target yang dilakukan secara berulang-ulang hingga mencapai sasaran; d) kejujuran, yaitu dengan memanah seorang pemanah harus jujur karena perkenaan anak panah tidak bisa di manipulasi; e) bersyukur, yaitu ketika memanah tepat pada sasarannya pemanah mengucapkan puji dan syukur; f) kesabaran, ketika anak panah yang dilepaskan ternyata meleset dari pusat sasaran, pemanah termotivasi untuk melepaskan anak panah hingga mengenai sasaran yang tepat. Karena belum diketahui secara pasti bahwa dalam olahraga panahan dapat memberikan pengembangan karakter atlet-atlet pelajar. Maka peneliti ingin melakukan sebuah penelitian terkait pendidikan karakter atlet pelajar melalui kegiatan olahraga panahan di Kabupaten Banyumas.

\section{METODE}

Penelitian ini adalah penelitian ex post facto, Metode yang digunakan dalam penelitian ini adalah survei. Teknik pengumpulan data yang digunakan dalam penelitian ini menggunakan instrumen yang berupa angket. Kegiatan pengambilan data penelitian dilakukan selama 2 hari yaitu lapangan panahan GOR Satria Purwokerto, lapangan Desa Beji, Kabupaten Banyumas pada tanggal 8 Febuari 2018 dan di lapangan SMP N 4 Purwokerto pada tanggal 10 Febuari 2018. Populasi terdiri dari atlet Sekolah Dasar sebanyak 23 Atlet, SMP sebanyak 40 Atlet, SMA sebanyak 25 sehingga total atlet pelajar panahan di kabupaten Banyumas berjumlah 88 atlet pelajar. Sampel dari penelitian ini berjumlah 30 orang atlet putra/putri yang ditentukan mengunakan purposive sampling dengan sarat atlet panahan dan masih pelajar.

Tabel 1. Kisi-Kisi Instrument Penelitian Karakter Atlet Pelajar Panahan di Kabupaten Banyumas

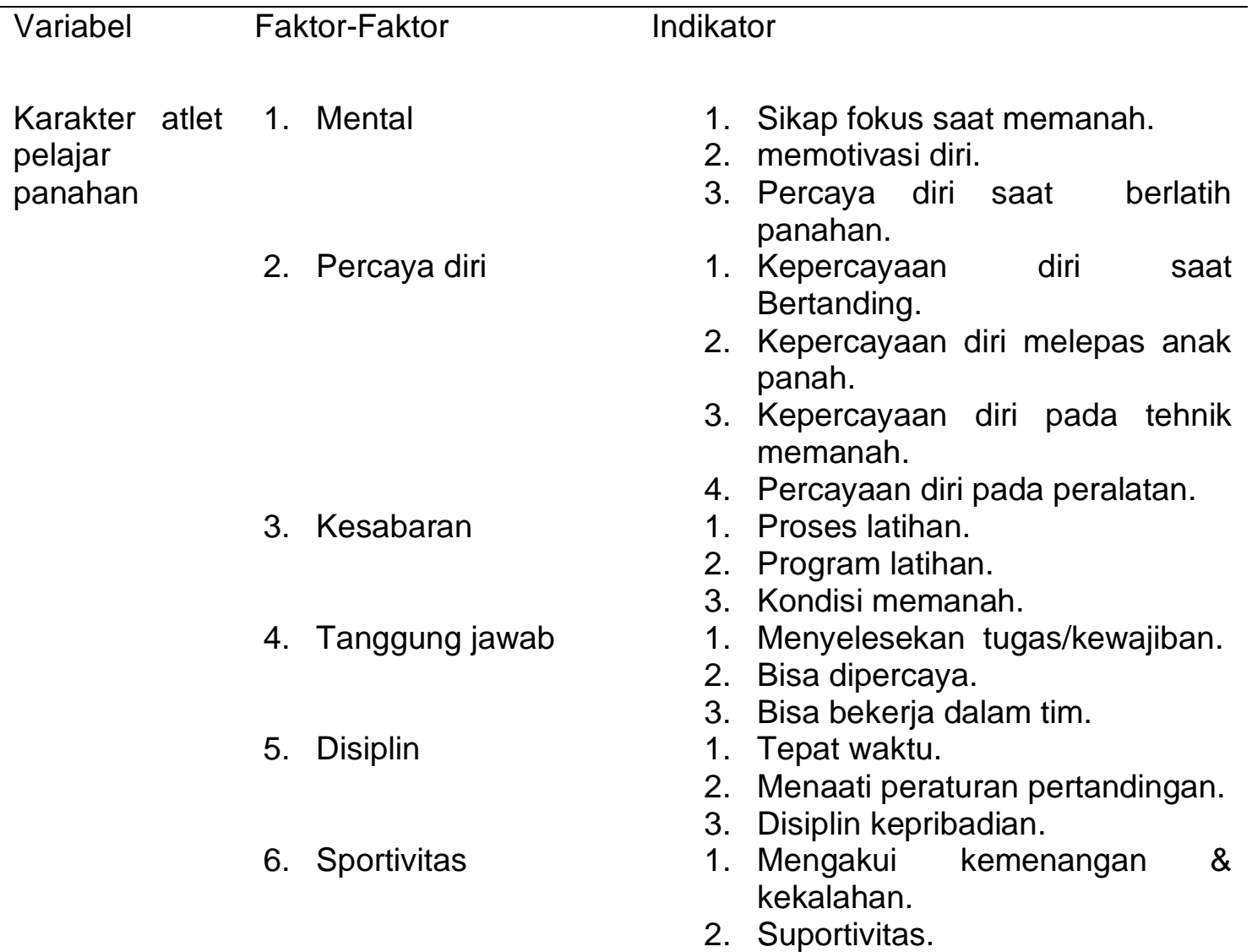


Angket ini di adopsi dari penelitian Kurniawati, (2018) kemudian uji validitasnya memakai rumus korelasi product moment \& uji reliabilitas cronbach's alpha 0,896. Tehnik pengumpulan data di penelitian ini dengan cara membagikan angket yang di isi oleh atlet. Proses pengumpulan data dilakukan dengan menyebarkan angket kuisoner sebanyak 40 pertanyaan kepercayaan diri kepada 30 atlet. Kemudian peneliti melakukan pengolahan data dan analisis data serta peneliti membuat kesimpulan dan saran hasil penelitian. instrumen berupa angket atau kuesioner yang berisi pertanyaan-pertanyaan tertulis, sehingga responden dalam mengisi angket dengan cara memberikan tanda checklist dengan ketterangan skala bertingkat dalam angket ini menggunakan modifikasi likert dengan 4 pilihan dengan jawaban Sangat Setuju (SS) diberi nilai 4, Setuju (S) diberi nilai 3, Kurang Setuju (KS) diberi nilai 2, dan Tidak Setuju (TS) diberi nilai 1.

\section{HASIL DAN PEMBAHASAN}

Hasil penelitian ini adalah untuk mengetahui karakter atlet pelajar panahan. Dari hasil faktor mental, percaya diri, kesabaran, tanggung jawab, disiplin dan sportivitas dengan uraian sebagai berikut

Tabel 2. Deskripsi Hasil Penelitian Karakter Atlet Pelajar Panahan di Kabupaten Banyumas

\begin{tabular}{llll}
\hline Interval & Kategori & Jumlah & Persen (\%) \\
$X>148,05$ & Sangat Baik & 4 & 10 \\
$139,03 X<148,05$ & Baik & 10 & 37,5 \\
$130,01 X<139,03$ & Cukup & 5 & 25 \\
$120,99 X<130,01$ & Kurang & 7 & 17,5 \\
$X<120,99$ & Sangat Kurang & 4 & 10 \\
Jumlah & & $\mathbf{3 0}$ & $\mathbf{1 0 0}$ \\
\hline
\end{tabular}

Berdasarkan tabel di atas diketahui peran pendidikan karakter atlet pelajar dalam mengikuti olahraga panahan di Kabupaten Banyumas sebagian besar pada kategori baik dengan persentase sebesar $37,5 \%$, pada ketegori cukup sebesar $25 \%$, pada kategori kurang sebesar $17,5 \%$ dan pada kategori sangat kurang sebesar $10 \%$ dan kategori sangat Baik $10 \%$

Tabel 3. Deskripsi Hasil Penelitian Faktor Mental

\begin{tabular}{llll}
\hline Interval & Kategori & Jumlah & Persen (\%) \\
$X>31,15$ & Sangat Baik & 1 & 2,5 \\
$28,53 X<31,15$ & Baik & 10 & 32,5 \\
$25,91 X<28,53$ & Cukup & 10 & 40 \\
$23,29 X<25,91$ & Kurang & 4 & 10 \\
$X<23,29$ & Sangat Kurang & 5 & 15 \\
Jumlah & & $\mathbf{3 0}$ & $\mathbf{1 0 0}$ \\
\hline
\end{tabular}

Berdasarkan tabel di atas diketahui faktor mental sebagian besar pada kategori cukup dengan persentase sebesar $40 \%$, pada kategori baik sebesar 32,5\%, pada ketegori sangat kurang sebesar $15 \%$, pada kategori kurang sebesar $10 \%$, dan pada kategori sangat Baik sebesar $2,5 \%$. 
Tabel 4. Deskripsi Hasil Penelitian Faktor Percaya Diri

\begin{tabular}{llll}
\hline Interval & Kategori & Jumlah & Persen (\%) \\
$X>27,31$ & Sangat Baik & 1 & 2,5 \\
$24,97 X<27,31$ & Baik & 13 & 42,5 \\
$22,63 X<24,97$ & Cukup & 5 & 10 \\
$20,29 X<22,63$ & Kurang & 5 & 10 \\
$X<20,29$ & Sangat Kurang & 6 & 15 \\
Jumlah & & $\mathbf{3 0}$ & $\mathbf{1 0 0}$ \\
\hline
\end{tabular}

Berdasarkan tabel di atas diketahui Faktor Percaya Diri sebagian besar pada kategori baik dengan persentase sebesar $42,5 \%$, pada kategori cukup sebesar $10 \%$, pada ketegori kurang sebesar $10 \%$, pada kategori sangat kurang sebesar $15 \%$, dan pada kategori sangat baik sebesar $2,5 \%$.

Tabel 5. Deskripsi Hasil Penelitian Faktor Kesabaran

\begin{tabular}{llll}
\hline Interval & Kategori & Jumlah & Persen (\%) \\
$X>26, \mathbf{1 2}$ & Sangat Baik & 1 & 2,5 \\
$23,57 X<26,12$ & Baik & 10 & 37,5 \\
$21,02 X<23,57$ & Cukup & 5 & 25 \\
$18,47 X<21,02$ & Kurang & 12 & 30 \\
$X<18,47$ & Sangat Kurang & 2 & 5 \\
Jumlah & & $\mathbf{3 0}$ & $\mathbf{1 0 0}$ \\
\hline
\end{tabular}

Berdasarkan tabel di atas diketahui faktor kesabaran sebagian besar pada kategori baik dengan persentase sebesar $37,5 \%$, pada kategori kurang sebesar $30 \%$, pada ketegori cukup baik sebesar $25 \%$, pada kategori sangat kurang sebesar $5 \%$, dan pada kategori sangat baik sebesar $2,5 \%$.

Tabel 6. Deskripsi Hasil Penelitian Faktor Tanggung Jawab

\begin{tabular}{llll}
\hline Interval & Kategori & Jumlah & Persen (\%) \\
$X>39,48$ & Sangat Baik & 1 & 2,5 \\
$36,87 X<39,48$ & Baik & 10 & 37,5 \\
$34,26 X<36,87$ & Cukup & 10 & 25 \\
$31,65 X<34,26$ & Kurang & 6 & 27,5 \\
$X<31,65$ & Sangat Kurang & 3 & 7,5 \\
Jumlah & & $\mathbf{3 0}$ & $\mathbf{1 0 0}$ \\
\hline
\end{tabular}

Berdasarkan tabel diatas diketahui Faktor Tanggung sebagian besar pada kategori baik dengan persentase sebesar 37,5 \%, pada kategori kurang sebesar 27,5\%, pada ketegori cukup sebesar $25 \%$, pada kategori sangat kurang sebesar 7,5\%, dan pada kategori sangat baik sebesar $2,55 \%$.

Tabel 7. Deskripsi Hasil Penelitian Faktor Sportivitas

\begin{tabular}{llll}
\hline Interval & Kategori & Jumlah & Persen (\%) \\
$X>14,56$ & Sangat Baik & 2 & 5 \\
$13,19 X<14,56$ & Baik & 7 & 17,5 \\
$11,82 X<13,19$ & Cukup & 13 & 35 \\
$10,45 X<11,82$ & Kurang & 6 & 15 \\
$X<10,45$ & Sangat Kurang & 2 & 5 \\
Jumlah & & $\mathbf{3 0}$ & $\mathbf{1 0 0}$ \\
\hline
\end{tabular}

Berdasarkan tabel diatas diketahui Faktor Sportivitas sebagian besar pada kategori cukup dengan persentase sebesar $35 \%$, pada kategori baik sebesar $17,5 \%$, pada ketegori kurang sebesar $15 \%$, pada kategori sangat kurang sebesar $5 \%$, dan pada kategori sangat baik 
sebesar $5 \%$. Hasil penelitian ini adalah untuk mengetahui karakter atlet pelajar panahan. Dari hasil faktor mental, percaya diri, kesabaran, tanggung jawab, disiplin dan sportivitas dengan uraian sebagai berikut:

\section{Faktor Mental}

Faktor mental di sini merupakan salah satu sikap fokus dalam memanah, dapat membantu dalam peran internalisasi pengembangan karakter atlet pelajar di Kabupaten Banyumas. Berdasarkan penelitian Wibowo and Rahayu (2016); Yachsie et al. (2021) berbagai faktor yang dapat meningkatkan atau menurunkan risiko kelainan mental, emosional dan perilaku pada remaja antara lain kompetensi dan karakteristik individu, keluarga, kualitas sekolah dan karakteristik di level komunitas. Berdasarkan penelitian Hasanah and Deiniatur (2020) Faktor-faktor tersebut cenderung memiliki efek kumulatif, dimana faktor risiko yang besar akan meningkatkan kemungkinan dampak negative. sedangkan menurut Sameroff and Seifer (2021) sejumlah besar faktor protektif akan menurunkan kemungkinan terjadinya dampak negatif. Berdasarkan Riset Kesehatan Dasar (Riskesdas) pada tahun 2017 dalam penelitian Kurniawati (2018), prevalensi masalah mental dan emosional pada orang Indonesia dengan usia di atas 15 tahun adalah 11.6\%.4 berdasarkan dalam penelitian yang dilakukan di Semarang diperoleh hasil bahwa sekitar $9,1 \%$ remaja SMP dan SMA di kota Semarang mempunyai masalah mental dan emosional.

Jadi kesimpulan di sini adalah salah satu komponen penting yang dapat menentukan kesuksesan atlet dalam berprestasi. Faktor mental dinilai dari nilai, sikap, perilaku, dan emosi yang memungkinkan seseorang mampu bertahan dan menghadapi berbagai hambatan, rintangan, atau tekanan yang dialami dengan tetap menjaga konsentrasi, motivasi, dankonsistensi seseorang dalam mencapai tujuan.

\section{Faktor Percaya Diri}

Faktor percaya diri ini berhubungan dengan kepercayaan diri saat melepaskan anak panah, Berdasarkan penelitian Green (2020) terdapat hasil yang signifikan dari hubungan kepercayaan diri ini dalam kepercayaan diri pada siswa. Selaras dengan penelitian Johnstone et al. (2020) tingginya tingkat percaya diri akan berdampak pada keberhasilannya, sedangkan siswa yang memiliki kepercayaan diri rendah akan mempengaruhi keberhasilannya dalam mencapai hasil yang maksimal. Senada dengan penelitian Wolfson et al., (2021; Yachsie et al., (2021) menyatakan bahwa jika kepercayaan diri seseorang terganggu maka konsentrasi saat melakukan pembelajaran maupun tehnik panahan akan berdampak pada hasil. Penelitian yang dilakukan oleh Mohammadi et al. (2016) juga mengungkapkan rasa percaya diri dan fokus merupakan faktor penting dalam proses meneria ilmu, seringkali seorang pelajar merasakan kurang percaya diri dan tidak fokus yang menyebabkan ilmu yang di ajarkan tidak mampu memahami secara akurat walaupun pada dasarnya pelajar tersebut memiliki kemampuan yang baik. dapat di simpulkan kepercayaan diri ini merupakan salah satu yang membantu mengembangkan karakter siswa melalui olahraga panahan.

\section{Faktor Kesabaran}

Penelitian ini mendapat hasil bahwa dalam mengontrol kesabaran atlet pelajar dapat berlatih mengontrol diri dengan cara mempraktekkan proses latihan. Menurut Branitska and Logutina (2020) pemusatan seluruh aktivitas individu terhadap suatu objek atau sekumpulan objek atau perangsang. Selaras dengan penelitian Abdurashidovich and Botir (2020) individu perlu memiliki kemampuan untuk bersabar dan memperhatikan informasi penting dan mengabaikan informasi yang tidak relevan. Pengertian yang lain dikemukakan oleh Sari (2020) mengemukakan bahwa meningkatkan kesabaran merupakan keaktifan peningkatan atensi seluruh fungsi jiwa yang diarahkan pada suatu objek baik yang berada di dalam maupun di luar dirinya. Dapat disimpulkan dengan mempraktekkan program latihan, tahapan pembelajaran tehnik saat memanah yang telah diajarkan oleh pelatih dan para atlet dapat mengaplikasikan 
kebiasaan-kebiasaan yang baik terakit dengan faktor kesabaran ini di dalam kehidupan sehariharinya.

\section{Faktor Tanggung jawab}

Dalam hal ini menunjukkan bahwa faktor tanggung jawab dalam pendidian karakter di olahraga panahan dapat di lakukan dengan atlet ketika belajar. Berdasarkan penelitian Russell \& Higgins, (2020; Yakovleva et al., (2020) tanggung jawab secara personal terhadap pelaksanaan tugas dan kewajiban, kooperatif antar atlet. Tanggung jawab belajar menurut Dadsena (2020) memiliki peranan yang sangat penting dalam upaya peningkatan pembelajaran, yaitu apabila dikehendaki peningkatan pembelajaran maka dibutuhkan tanggung jawab belajar yang lebih besar dalam pelaksanaan proses pembelajaran. Selaras dengan penelian $\mathrm{Vu}$ et al. (2020) tanggung jawab merupakan sesuatu yang harus dilakukan dan merupakan suatu kewajiban yang harus dimiliki atlet pelajar. Jadi di simpulkan dimana kondisi belajar maupun kondisi pertandingan atlet harus bisa bertanggung jawab dan berkomitmen jika pertandingan maupun belajar di sekolahan merupakan bagian dari proses keberhasilan dari sebuah proses menjadi yang terbaik.

\section{Faktor Disiplin}

Diperoleh hasil penelitian dalam hal ini menunjukkan bahwa dalam faktor disiplin atlet pelajar dapat mengaplikasikan sikap disiplin pada saat latihan maupun bertanding, kemudian juga dapat dengan mengikuti secara tertib peraturan pertandingan dengan baik hal tersebut jika dapat dilakukan oleh seorang atlet pelajar dengan konsekuen akan membentuk karakter baik yaitu disiplin. Berdasarkan penelitian Sin (2017) berhasilnya sebuah proses latihan yang dilakukan merupakan hal paling diharapkan dari setiap latihan dalam berbagai aktivitas, salah satunya adalah aktivitas olahraga. Selaras dengan penelitian Fraczek et al. (2020) yaitu berkaitan lansung dengan fisik. Berdasarkan penelitian Liang et al. (2020) masalah latihan fisik seringkali dihadapkan pada persoalaan seperti, tidak sesuainya hasil latihan dengan yang diharapkan. Namun meurut penelitian Kozina et al. (2020) upaya yang dilakukan dalam mencapai latihan yang optimal adalah menanamkan disiplin kepada atlet yang mengikuti latihan, dengan demikian disiplin dalam latihan ini harus dimiliki oleh setiap atlet yang bertujuan untuk mencapai prestasi optimal. Jadi dari beberapa pendapat di atas di simpulkan faktor disiplin adalah kunci utama dalam mencapai sebuah latihan yang optimal.

\section{Sportivitas}

Diperoleh hasil dalam hal ini menunjukkan bahwa dalam faktor sportivitas, atlet dapat mengaplikasikan sikap sportivitas ketika seorang atlet dapat bersikap mengakui keunggulan lawan, dan dapat menjaga kekompakan dan sportivitas antar timnya.

Berdasarkan penelitian Syarnubi et al. (2020) secara umum sportivitas diidentifikasikan sebagai perilaku yang menunjukan sikap hormat dan adil terhadap orang lain serta sikap menerima dengan baik apapun hasil dari suatu pertandingan. Selaras dengan penelitian Demers (2020) sportivitas sebagai perilaku yang ditunjukan oleh atlet, pelatih, administrator dan penonton dalam kompetisi atletik. Definisi lain dari sportivitas menurut Parent et al. (2020) adalah sikap dan perilaku yang ditunjukan oleh individu dalam setting olahraga yang menunjukan penghormatan terhadap aturan, official, konvesi sosial dan hormat pada lawan yang diikuti dengan komitmen terhadap olahraga itu sendiri dan tidak melakukan partisipasi olahraga yang negatif. Dari beberapa penelitian di atas didapat kesimpulan bahwa individu yang memiliki sportivitas yang baik akan perilaku seperti jabat tangan dengan lawan, memberikan dukungan baik kepada teman satu tim maupun lawan, mau memberikan selamat kepada lawan yang menunjukan performansi yang baik, dan menunjukkan usaha maksimum dalam bermain dan berlatih.

Berdasarkan hasil penelitian secara keseluruhan karakter atlet pelajar panahan di Kabupaten Banyumas sebagian besar pada kategori baik dengan mengutamakan faktor-faktor nilai karakter dalam panahan. Dalam hal ini aplikasinya dalam olahraga panahan yaitu harus 
fokus, tenang dan konsentrasi terhadap bidikan dengan demikian mental anak dapat tercipta dengan baik, hal tersebut dikarenakan anak dilatih untuk mempunyai mental yang berani, tidak takut (Verawati \& Valianto, 2020). Sikap percaya diri akan tercipta dengan pengalaman bertanding, sikap atlet saat menerapkan tehnik panahan dengan baik (Musa et al., 2019). Olahraga panahan juga akan melatih kesabaran seseorang, dikarenakan saat melakukan panahan seorang atlet harus sabar dalam membidik sasaran menyesuaikan kondisi angin dan cuaca (Fadda \& Touqan, 2012). Selanjutnya yaitu sikap disiplin di dapat ketika seorang atlet harus bersama-sama saat mengambil anak panah, karena jika kita tidak menerapkan sikap disiplin pada saat mengambil anak panah akan berakibat fatal dan dapat mencelakakan oranglain (Sari, 2020). Berdasarkan hasil yang telah diteliti di dapat bahwa nilai mental, percaya diri, kesabaran, tanggung jawab, disiplin, dan sportivitas. Di dukung penelitian (Zaharia, 2020; Jacinto Jr, 2021; Parenteau, 2021; Weekes \& Ryan, 2021) sebuah pengalaman olahraga bisa membangun karakter, akan tetapi jika lingkungannya terstruktur serta tujuan yang dinyatakan dan direncanakan adalah mengembangkan karakter. Dengan ini di sipulkan bahwa lingkungan harus mencakup semua individu yang merupakan pemangku kepentingan dalam lingkungan olahraga. Penelitian ini sudah dilakukan dengan sebaik mungkin namun tidak menutup kemungkinan memiliki keterbatasan penelitian yaitu saat melakukan pendataan ada beberapa atlet yang belum memahami konsep yang di jelaskan, oleh karena itu penelitian ini tetap didamping orang tua atlet .

\section{SIMPULAN DAN SARAN}

Penelitian ini didapat ada beberapa faktor yang mempengaruhi pendidikan karakter, yaitu: 1) faktor percaya diri; 2) faktor kesabaran; 3) faktor tanggung jawab; 4) faktor disiplin; 5) sportivitas, artinya faktor-faktor tersebut membantu untuk meningkatkan personalitas atlet panahan kususnya atlet panahan yang masih bersetatus pelajar dan dapat meningkatkan prestasi akademik serta prestasi menjadi pemenang dalam sebuah pertandingan olahraga, oleh karena itu didapat kesimpulan bahwa karakter atlet remaja yang ada di Banyumas tergolong dalam kategori baik. Dari penelitian ini mungkin bisa dijadikan reverensi para penulis untuk membuat penelitian yang relevan terkait faktor-faktor percaya diri, kesabaran, tanggung jawab, disiplin dan sportivitas dari cabang olahraga yang lain.

\section{DAFTAR PUSTAKA}

Abdurashidovich, T. M., \& Botir, U. (2020). YOUTH EDUCATION IS A KEY FACTOR OF THE COUNTRY'S WELL-BEING. INTERNATIONAL JOURNAL OF DISCOURSE ON INNOVATION, INTEGRATION AND EDUCATION, 1(5), 338-342.

Alif, S., Irwan, A., \& Elihami, E. (2020). Forming Characters Of Early Children In Non-Formal Education Units. Jurnal Edukasi Nonformal, 1(1), 88-94.

Branitska, T., \& Logutina, N. (2020). The intercultural competence of a new Ukrainian school teacher as an important factor of effective pedagogical activity. Journal "ScienceRise: Pedagogical Education». 2020.№ 4 (37). P. 13-19.

Chanifah, N., \& Samsudin, A. (2020). Pendidikan Karakter Islami: Karakter Ulul Albab Di Dalam Al-Qur'an.

Dadsena, P. (2020). The Age Factor of Criminal Responsibility of Juveniles in India: A Global Scenario. GIS Business, 15(4), 750-761.

Demers, E. (2020). La violence sexuelle vécue par les jeunes athlètes en contexte sportif: liens avec la conformité à l'éthique du sport.

Fadda, S., \& Touqan, M. (2012). Archery Safer than Ever Before.

Fraczek, B., Gacek, M., Pieta, A., Tyrala, F., Mazur-Kurach, P., \& Karpecka, E. (2020). Dietary mistakes of Polish athletes in relation to the frequency of consuming foods recommended 
in the Swiss food pyramid for active people. Roczniki Państwowego Zakładu Higieny, 71(1).

Green, L. (2020). Confident, capable and world changing: teenagers and digital citizenship. Communication Research and Practice, 6(1), 6-19.

Hasanah, U., \& Deiniatur, M. (2020). Character education in early childhood based on family. Early Childhood Research Journal (ECRJ), 2(1), 29-42.

Hermino, A., \& Arifin, I. (2020). Contextual Character Education for Students in the Senior High School. European Journal of Educational Research, 9(3), 1009-1023.

Johnstone, K. M., Middleton, T., Kemps, E., \& Chen, J. (2020). A pilot investigation of universal school-based prevention programs for anxiety and depression symptomology in children: A randomized controlled trial. Journal of Clinical Psychology, 76(7), 1193-1216.

Kozina, Z., Uvarova, N., Kniaz, H., Chernozub, A., Shkrebtii, Y., Romantsova, Y., Goncharenko, V., Goncharenko, O., \& Kholodniy, A. (2020). Predictive Modeling of the Forecast in the Olympic Discipline" Climbing Combined" Depending on the Results in Various Types of Climbing among Elite Athletes. International Journal of Applied Exercise Physiology, 9(3), 140-153.

Kurniawati, I. S. (2018). Karakter Atlet Pelajar Panahan Di Kabupaten Kulon Progo. In universitas negeri yogyakarta (Vol. 53, Issue 9).

Liang, W., Wang, D. D., Shang, B. R., Zhang, C.-Q., Duan, Y. P., \& Si, G. Y. (2020). Further examination of the psychometric properties of the Brief Self-Control Scale: evidence from Chinese athletes and students. International Journal of Sport and Exercise Psychology, $1-20$.

Mackenzie, V. (2017). The Revolutionary Life of Freda Bedi: British Feminist, Indian Nationalist, Buddhist Nun. Shambhala Publications.

Mohammadi, S. F., Amiri, M. A., Naderifar, H., Rakhshi, E., Vakilian, B., Ashrafi, E., \& BeheshtNejad, A.-H. (2016). Vision Examination Protocol for Archery Athletes Along with an introduction to sports visión. Asian Journal of Sports Medicine, 7(1).

Musa, R. M., Abdullah, M. R., Juahir, H., Eswaramoorthi, V., Alias, N., Hashim, M. R., \& Alnamat, A. S. F. (2019). An Exploratory Study of Personality Traits and Psychological Coping Skills on Archery Performance. Indian Journal of Public Health Research \& Development, 10(3).

Parent, S., Kotiuga, J., Vertommen, T., \& Fortier, K. (2020). Exploring the links between selfdirected violence and child maltreatment and bullying in sport. Routledge Handbook of Athlete Welfare, 128.

Putri, H. berliana. del. (2019). profil status sosial ekonomi orang tua ingkungan sosial dan motivasi atlet panahan di Kabupaten Klaten. Journal of Chemical Information and Modeling, 53(9), 1689-1699.

Rukmini, R. (2021). PENGUATAN PENDIDIKAN KARAKTER MELALUI PENGEMBANGAN BUDAYA SEKOLAH. Jurnal Ilmiah Pro Guru, 6(2), 173-180.

Russell, D., \& Higgins, D. (2020). Safeguarding capabilities in preventing child sexual abuse: exploratory factor analysis of a scale measuring safeguarding capabilities in youth-serving organizations workers. Child Maltreatment, 25(2), 233-242.

Sameroff, A. J., \& Seifer, R. (2021). Accumulation of environmental risk and child mental health. In Children of poverty (pp. 233-258). Routledge. 
Sari, E. R. (2020). Perlindungan Hukum Terhadap Kesejahteraan Pelaku Olahraga Panahan Di Jawa Tengah Berdasarkan Undang- Undang Nomor 3 Tahun 2005 Tentang Sistem Keolahragaan Nasional. Universitas Negeri Semarang. https://lib.unnes.ac.id/30216/

Sari, F. A. (2020). The Effect of Children's Sleep Pattern On Creativity. Early Childhood Research Journal (ECRJ), 3(2), 97-116.

Sin, T. H. (2017). Disiplin Atlet Dalam Latihan. Sporta Saintika, 2(1), 240-251. http://sportasaintika.ppj.unp.ac.id/index.php/sporta/article/download/46/18/

Sumaryanto, S. (2015). Perspektif Filsafat Olahraga Dalam Mewujudkan Masyarakat Sehat. Medikora, IX(1). https://doi.org/10.21831/medikora.v0i1.4646

Suratmin, Artanayasa, I. W., \& Budiawan, M. (2018). Pola Pembinaan Cabang Olahraga Pelajar Dalam Membangun Prestasi Olahraga Bali. JURNAL PENJAKORA, 53(9), 16891699.

Syarnubi, K. L., Lang, J. C. F., Marta, R. F., Santoso, N. R., \& Misnawati, D. (2020). The language uniqueness in family communication shapes children's learning patterns as esports athletes. Jurnal SPORTIF: Jurnal Penelitian Pembelajaran, 6(3), 624-629.

Vanagosi, K. D., \& Dewi, P. P. C. (2019). Evaluasi Program Pembinaan Prestasi Cabang Olahraga Panahan Di Bali. JURNAL PENJAKORA, 6(1).

Verawati, I., \& Valianto, B. (2020). The Effects of Progressive Muscle Relaxation on Concentration in Archery Atheletes at the UNIMED Club. 1st Unimed International Conference on Sport Science (UnICoSS 2019), 68-71.

Vu, K. T. T., Cheah, C. S. L., Sun, S., Zhou, N., \& Xue, X. (2020). Adaptation and assessment of the Child Feeding Questionnaire for Chinese immigrant families of young children in the United States. Child: Care, Health and Development, 46(1), 74-82.

Wibowo, S. A. P., \& Rahayu, N. I. (2016). Pengaruh Latihan Mental Imagery Terhadap Hasil Tembakan Atlet Menembak Rifle Jawa Barat. JTIKOR (Jurnal Terapan IImu Keolahragaan), 1(2), 23-29.

Wolfson, D. B., Warshaw, J. S., \& Coleman, J. C. (2021). Changing the Improvement Paradigm for Our Kids. In Patient Safety and Quality Improvement in Healthcare (pp. 353-373). Springer.

Yachsie, B. T. P. W. B. (2019). Pengaruh Latihan Dumbell-Thera Band Terhadap Daya Tahan Otot Lengan Dan Akurasi Memanah Pada Atlet Panahan. Medikora, 18(2), 79-85. https://doi.org/10.21831/medikora.v18i2.29200

Zaharia, N. (2020). Do Olympic Medalists Possess More Leadership Characteristics than Olympic Non-Medalists? United States Sports Academy. 